\title{
Laparoscopic Ovarian Drilling in Polycystic Ovarian disease patients: is it hazardous?
}

Taher Mostafa

Corresponding author:

Taher Mostafa

\section{$\underline{\text { Abstract }}$}

Objective: to evaluate the outcomes of endoscopic ovarian drilling (LOD) on the Anti Mullerian hormone (AMH) plasma levels, potential changes of the stromal ovarian blood flow, and antral follicular count by three-dimensional power Doppler ultrasonography in an-ovulatory polycystic ovarian disease (PCOD) and if this can explain the ovarian drilling mechanism of action.

Methods: The prospective, comparative (case control) research was completed on fifty patients from Bab El-Shaarea University Hospital (El Sayed Galal). They were selected from infertility and family planning clinics. Women were assigned into one of two equal groups (each 25 patients). The first included infertile women, resistant to clomiphene citrate and scheduled for drilling. The second included healthy women from the family planning clinic, who were seeking for contraception. The main outcomes were AMH levels, Doppler indices and Antral follicular counts before and after drilling. The secondary outcome in the study group included occurrence of ovulation, chemical and clinical pregnancy rate within 6 months after drilling.

Results: The mean initial $\mathrm{AMH}$, doppler indices and antral follicular counts were singingly higher among study than control group. AMH and AFC significantly reduced in cases after than before drilling [2.8 to 3.9], [13.9 to 15.8]. Ovarian FI, VI, and VFI significantly decreased after than before drilling. In the study group, $20(80 \%)$ had ovulation, and $13(52 \%)$ got pregnant within 6 months of the operation. Regression analysis showed that initial $\mathrm{AMH}$, initial $\mathrm{AFC}$, initial VFI, post-LOD AMH, post-LOD AFC, post-LOD VI, post-LOD FI and post-LOD VFI were significant indicators of successful ovulation and successful pregnancy within 6 months after drilling.

Conclusion: Endoscopic ovarian drilling had a significant decreasing effect on serum AMH, AFC, and Ovarian Doppler indices in PCOD patient not responding to clomiphene citrate. The initial values of $\mathrm{AMH}, \mathrm{AFC}$ and VFI; besides post-drilling values of $\mathrm{AMH}, \mathrm{AFC}, \mathrm{VI}, \mathrm{FI}$, and VFI were significant indicators of ovulation after drilling.

Keywords: Laparoscopic; Ovarian Drilling; Polycystic Ovarian Disease; Anti Mullerian Hormone. 


\section{$\underline{\text { Introduction }}$}

Polycystic ovarian disease (PCOD) is a disorder that hits $5-10 \%$ of females of reproductive age group (1). Twelve or more follicles with a dimeter of $2-9 \mathrm{~mm}$ or increased the volume of ovaries $(>10 \mathrm{~cm} 3)$ must be present to diagnose the condition by trans-vaginal scanning (2).

Definition of PCOD requires the existence of at least 2 of the next 3 diagnostic criteria: oligo-ovulation and/or anovulation, clinical and/or laboratory features of hyper-androgenism, and ultrasonic polycystic ovarian features (3).

Rising blood flow of ovarian stroma is emerging as an indicator to help in the diagnosis. The average time of maximum ovarian velocity and stromal peak systolic blood flow velocity were significantly higher in PCOD than in normal females (4).

Three-dimensional power Doppler showed significantly higher blood flow of the ovarian stroma in PCOD than in normal ovaries (5).

The pattern assessment of blood flow by $2 \mathrm{D}$ ultra-sonography, can be achieved by objective measurement of velocity and the resistance to flow by pulsed-wave Doppler with subsequent analysis of the waveforms derived from a single vessel or by applying color or 2D power Doppler to a single plane (6).

Color Doppler is less sensitive than Power Doppler for detection of low flow velocity, and thus it overcomes the angle dependence of standard color Doppler and provides improved visualization of small vessels (7).

Anti-Mullerian hormone (AMH) belong to the family of transforming growth factor- $\beta$ (TGF- $\beta$ ). AMH is mainly secreted by the granulosa cells (GCs) of early ovarian developing follicles (8). Its expression is limited to GCs of primary, pre antral, and small antral follicles, suggesting that, it plays a crucial role in folliculogenesis (9).
It was demonstrated that $\mathrm{AMH}$ reduces the follicles sensitivity to circulating $\mathrm{FSH}$, an effect that is significant for normal folliculogenesis, also it was shown that AMH is two to threefold rise-up in serum of PCOD than females with intact ovaries (10).

Controversial information is now available regarding whether an intrinsic AMH production by the GCs played a role or cause follicular arrest in PCOD or the AMH excess in PCOD is secondary to the rise in pre-antral follicles number (11).

Increased AMH concentrations may be related to other factors in PCOD, the most obvious being hyper-androgenism (12) and increased resistance to insulin (13).

Increased flow of stromal ovarian blood in PCOD may result from increased production of vascular endothelial growth factor (VEGF), which may modulate the increased insulin-like growth factor I (IGF-I), that enhances gonadotropin stimulated steroid formation in GCs and theca cells, resulting in increased ovarian production of androgens and subsequently increased $\mathrm{AMH}$ production (13) and the vascular permeability of theca cells (14).

Knowing factors that determine the response of females with PCOD to drilling will help in selecting cases that may benefit from this treatment modality (15). Factors affecting the success of LOD was reported in a previous study (16).

AMH had been discovered to correlate with ovarian responsiveness to clomiphene citrate (CC) (17) and to FSH controlled ovarian hyper-stimulation for IVF cycles (18). $\mathrm{AMH}$ serum level consistency along the menstrual cycle, with very little inter cycle variability, makes it an attractive indictor of response to treatment (19). LOD mechanism is not yet unexplained. Particularly, it is not accurately known whether drilling exerts its effect by a systemic endocrine mechanisms or through a direct action on the ovary (20). 


\section{Patients and Methods}

The current work was performed at Al-Sayed Galal University Hospital between Marsh 2015 and December 2016. It was a prospective case control study that was held on fifty patients divided into 2 groups. Case group included 25 infertile patients of PCOD not responding to clomiphene citrate and exposed to endoscopic ovarian drilling, and Control group includes 25 healthy patients from family planning clinic seeking for contraception.

\section{Inclusion Criteria:}

1. Age between 18-35 years old.

2. Diagnostic features for PCOD included at least 2 of the next 3 features according to Rotterdam ESHRE 2004 :

a)Amenorrhea or oligomenorrhea with chronic anovulation.

b)Clinical and/or labortory evidence of hyperandrogenism.

c)Ultra-sonographic criteria of PCOS.

3. Ovulation failure after administration of CC up to a $150 \mathrm{mg}$, daily dose from cycle days 2-6 for three consecutive cycles.

4. Ovaries were classified as normal or polycystic by ultrasonic examination, the follicle number of $0.2-0.9 \mathrm{~cm}$ in diameter will be counted in both ovaries. The threshold will be established at 12 , thus diagnosing polycystic ovaries by the existence of 12 or more follicles. If the average follicle number is less than 12 , the ovaries will be considered as normal (21).

\section{Exclusion Criteria:}

1. Age $<18$ or $>35$ years.

2. Infertility due to male factor.

3. Tubal Factor investigated with hystero-salpingography.

4. Previous or current use of metformin.

5. Diseases potentially affecting the ovarian environment and/or function (including leiomyomas and endometriosis) or any organic pelvic diseases.
6. Women with single ovary.

7. Previous ovarian cystectomy.

8. Hyper-prolactinemia.

9. Thyroid disease.

10. Diabetes mellitus.

\section{Procedure}

$>$ For all participants, the age and body mass index (BMI) were recorded. Drilling was performed in the follicular phase of the menstrual cycle. Cauterization of each ovary at 4 points, for 4 seconds at each point, using $40 \mathrm{~W}$ of power with a high-frequency monopolar current microneedle, $10 \mathrm{~mm}$ long regardless of the size of the ovary.

$>$ On the morning of the 3rd day of the same cycle in which the operation would to be performed, a sample of blood was drawn from each patient before drilling for $\mathrm{AMH}$ assay.

$>$ Another blood sample was drawn on the third day of the first post-LOD cycle. Blood samples were drawn also from the control women on the third day of the menstrual cycle.

$>\mathrm{AFC}$ was obtained in the follicular phase before LOD and repeated in the follicular phase of the first post-LOD cycle. However, the AFC was examined also in the follicular phase of any cycle in the control group.

$>$ A conventional 3D power Doppler ultrasound system having the VOCAL program (Virtual Organ Computer Aided Analysis) was used. Evaluation was performed for both ovaries excluding the ovarian vessels. The site of interest included the whole ovary except for the ovarian vessels.

$>$ Examination was performed in the follicular phase prior to LOD and was repeated in the follicular phase of the first cycle 
after LOD. Examination was done in the follicular phase of any cycle in the control group. Three indices were calculated: flow index (FI); vascularization index (VI); and vascularization flow index (VFI).

$>$ The measured items between the 2 groups were compared using the Student t test. Comparisons of values before and after drilling in the PCOD group were done by the paired t test. $\mathrm{P}$ value $<0.05$ will be considered to be statistically significant.

$>$ Follow up of the case group patients was done by doing folliculometry monthly for 6 successive months within them the patients receive clomiphene citrate of a daily dose of $150 \mathrm{mg}$ from the day 3rd to the 7 th day.

$>$ The 1ry outcomes were:

$>$ AMH level before and after drilling in case group and its relation with it in the control group. The change in the measures of the 3D power Doppler indices of the stromal ovarian blood flow before and after the operation in case group and its relation to them in the control group.

$>$ The change in antral follicle count before and after drilling in case group and its relation with it in the control group.
$>$ The 2ry outcomes were:

$>$ Ovulation occurrence in the case group patients within 6 months of the operation and with ovulation induction using clomiphene citrate $150 \mathrm{mg}$ daily from 3rd to day 7 th day.

$>$ Pregnancy occurrence in the case group patients within 6 months of the operation and with ovulation induction using clomiphene citrate of a daily dose of $150 \mathrm{mg}$ from the $3 \mathrm{rd}$ to the $7^{\text {th }}$ day of the cycle.

\section{$\underline{\text { Statistical Analysis }}$}

Statistical analysis was done using SPSS for Windows version 15.0. Data were presented as range, mean and standard deviation (for parametric variables), number and proportion (for categorical variables). Difference between both groups was analyzed using independent student's t-test (for parametric variables), Fischer's exact or chi-squared (for categorical data). Association between variables was estimated using Pearson's correlation coefficient (for parametric variables) and Spearman's correlation coefficient (for non-parametric variables). Significance level was set at 0.05 .

\section{Statistical Analysis}

Table-1 Difference between Groups regarding Initial Characteristics

\begin{tabular}{|l|c|c|c|c|}
\hline & $\begin{array}{c}\text { Group I } \\
\text { [PCOS Group] } \\
\text { (n=25) }\end{array}$ & $\begin{array}{c}\text { Group II } \\
\text { [Control Group] } \\
\text { (n=25) }\end{array}$ & $\begin{array}{c}\text { MD/OR } \\
\text { (95\% CI) }\end{array}$ & P \\
\hline $\begin{array}{l}\text { Age (years) } \\
\text { Range } \\
\text { Mean } \pm \text { SD }\end{array}$ & $19-33$ & $18-34$ & -1.6 & $0.901^{1}$ \\
\hline $\begin{array}{l}\text { Parity } \\
\mathbf{0}\end{array}$ & $26.2 \pm 4.27$ & $26.36 \pm 4.75$ & $(-2.7$ to 2.4$)$ & NS \\
\hline $\mathbf{1}$ & $20(80 \%)$ & $0(0 \%)$ & & $<0.001^{2}$ \\
\hline $\begin{array}{l}\text { No. of Miscarriages } \\
\mathbf{0}\end{array}$ & $5(20 \%)$ & $25(100 \%)$ & NE \\
\hline $\mathbf{1}-\mathbf{2}$ & $16(64 \%)$ & $21(84 \%)$ & 0.34 & $0.107^{2}$ \\
\hline
\end{tabular}




\begin{tabular}{|l|c|c|c|c|}
\hline Weight (kg) & & & & \\
Range & $58-90$ & $58-88$ & -0.6 & $0.814^{1}$ \\
Mean \pm SD & $70.6 \pm 9.49$ & $71.2 \pm 9.6$ & NS \\
\hline BMI (kg/m2) & & & & \\
Range & $23.34-29.74$ & $22.66-29.07$ & 0.9 & $0.123^{1}$ \\
Mean \pm SD & 26.581 .85 & $25.73 \pm 2.01$ & $(-0.2$ to 1.95$)$ & NS \\
\hline
\end{tabular}

SD standard deviation

IQR interquartile range

MD (95\% CI) mean difference and its 95\% confidence interval

OR $(95 \% \mathrm{CI})$ odds ratio and its $95 \%$ confidence interval

1 Analysis using independent student's t-test

2 Analysis using chi-squared test

NS non-significant - HS highly significant

NE not estimable

Table-2 Difference between Groups regarding Initial Serum AMH and AFC

\begin{tabular}{|c|c|c|c|c|}
\hline & $\begin{array}{c}\text { Group I } \\
\text { [PCOS Group] } \\
(n=25)\end{array}$ & $\begin{array}{c}\text { Group II } \\
\text { [Control Group] } \\
(\mathbf{n}=\mathbf{2 5})\end{array}$ & $\begin{array}{c}\text { MD } \\
(95 \% \mathrm{CI})\end{array}$ & $\mathbf{P}$ \\
\hline $\begin{array}{l}\text { Initial Serum AMH }(\mathrm{ng} / \mathrm{ml}) \\
\text { Range } \\
\text { Mean } \pm \text { SD }\end{array}$ & $\begin{array}{c}3.2-11.6 \\
7.19 \pm 2.45\end{array}$ & $\begin{array}{c}1.2-3.8 \\
2.23 \pm 0.69\end{array}$ & $\begin{array}{c}4.96 \\
\text { (3.9 to } 5.9)\end{array}$ & $\begin{array}{c}<0.001^{1} \\
\text { HS }\end{array}$ \\
\hline $\begin{array}{l}\text { Initial AFC } \\
\text { Range } \\
\text { Median (IQR) }\end{array}$ & $\begin{array}{c}24-36 \\
29(27-30)\end{array}$ & $\begin{array}{c}8-18 \\
12(10-14)\end{array}$ & $\begin{array}{c}16.9 \\
(15.3 \text { to } \\
18.5)\end{array}$ & $\begin{array}{c}<0.001^{2} \\
\text { HS }\end{array}$ \\
\hline
\end{tabular}

SD standard deviation

IQR interquartile range

MD (95\% CI) mean difference and its 95\% confidence interval

1 Analysis using independent student's t-test

2 Analysis using Mann-Whitney's U-test

HS highly significant

Table-3 Difference between Groups regarding Initial 3D Power Doppler Indices

\begin{tabular}{|l|c|c|c|c|}
\hline & $\begin{array}{c}\text { Group I } \\
\text { [PCOS Group] } \\
\text { (n=25) }\end{array}$ & $\begin{array}{c}\text { Group II } \\
\text { [Control Group] } \\
\text { (n=25) }\end{array}$ & $\begin{array}{c}\text { MD } \\
\text { (95\% CI) }\end{array}$ & P \\
\hline $\begin{array}{l}\text { Initial VI } \\
\text { Range }\end{array}$ & $3.2-6.5$ & $1.2-2.5$ & 3.01 & $<0.001^{1}$ \\
Mean \pm SD & $4.84 \pm 1.08$ & $1.84 \pm 0.36$ & $(2.5$ to 3.5$)$ & HS \\
\hline $\begin{array}{l}\text { Initial FI } \\
\text { Range }\end{array}$ & $47.1-57.1$ & $37.2-48.3$ & 10.63 & $<0.001^{1}$ \\
Mean \pm SD & $52.45 \pm 3.46$ & $41.81 \pm 3.21$ & $(8.7$ to 12.5$)$ & HS \\
\hline $\begin{array}{l}\text { Initial VFI } \\
\text { Range }\end{array}$ & $2.2-3.5$ & $0.5-1.3$ & 1.98 & $<0.001^{1}$ \\
Mean \pm SD & $2.89 \pm 0.41$ & $0.92 \pm 0.25$ & $(1.8$ to 2.2) & HS \\
\hline
\end{tabular}

SD standard deviation

VI vascularization index 
FI flow index

VFI vascularization flow index

MD (95\% CI) mean difference and its 95\% confidence interval

1 Analysis using independent student's t-test

HS highly significant

Table-4 Difference between Pre- and Post-LOD Serum AMH and AFC

\begin{tabular}{|l|c|c|c|c|}
\hline $\begin{array}{l}\text { Group I } \\
\text { [PCOS Group] }\end{array}$ & Pre-LOD & Post-LOD & $\begin{array}{c}\text { MPD } \\
\text { (95\% CI) }\end{array}$ & P \\
\hline $\begin{array}{l}\text { Serum AMH } \\
\text { (ng/ml) }\end{array}$ & & & & \\
Range & $3.2-11.6$ & $1.8-6.9$ & 3.34 & $<0.001^{1}$ \\
Mean \pm SD & $7.19 \pm 2.45$ & $3.84 \pm 1.51$ & $(2.8$ to 3.9$)$ & HS \\
\hline $\begin{array}{l}\text { AFC } \\
\text { Range }\end{array}$ & $24-36$ & $10-19$ & 14.9 & $<0.001^{2}$ \\
Median (IQR) & $29(27-30)$ & $14(12-16)$ & $(13.9$ to 15.8$)$ & HS \\
\hline
\end{tabular}

SD standard deviation

IQR interquartile range

MPD (95\% CI) mean paired difference and its 95\% confidence interval

1 Analysis using paired student's t-test

2 Analysis using Wilcoxon signed rank test

HS highly significant

Table-5 Difference between Pre- and Post-LOD 3D Power Doppler Indices

\begin{tabular}{|l|c|c|c|c|}
\hline $\begin{array}{l}\text { Group I } \\
\text { [PCOS Group] }\end{array}$ & Pre-LOD & Post-LOD & $\begin{array}{c}\text { MPD } \\
\text { (95\% CI) }\end{array}$ & P \\
\hline Initial VI & $3.2-6.5$ & $1.4-3.5$ & 2.56 & $<0.001^{1}$ \\
Range & $4.84 \pm 1.08$ & $2.28 \pm 0.62$ & $(2.3$ to 2.8$)$ & HS \\
Mean \pm SD & $47.1-57.1$ & $40.5-47.5$ & & \\
\hline Initial FI & $52.45 \pm 3.46$ & $43.42 \pm 2.22$ & $(8.2$ to 9.9$)$ & $<0.001^{1}$ \\
Range & & & & HS \\
Mean \pm SD & $2.2-3.5$ & $0.5-1.95$ & 1.79 & $<0.001^{1}$ \\
\hline Initial VFI & $2.89 \pm 0.41$ & $1.1 \pm 0.54$ & $(1.7$ to 1.9$)$ & HS \\
\hline Range & & \\
Mean \pm SD & &
\end{tabular}

SD standard deviation

VI vascularization index

FI flow index

MPD (95\% CI) mean paired difference and its 95\% confidence interval

1 Analysis using paired student's t-test

HS highly significant

Table-6 Incidence of Ovulation and Pregnancy within 6 months among Women of Group I [PCOD Group]

\begin{tabular}{|l|l|}
\hline Ovulation within 6 months & $20(80 \%)$ \\
\hline Pregnancy within 6 months & $13(52 \%)$ \\
\hline
\end{tabular}

Data presented as number (percentage) 
Table-7 Binary Logistic Regression Analysis for Measured Variables as indicator of pregnancy and Ovulation within 6 months after LOD

\begin{tabular}{|c|c|c|c|c|}
\hline & \multicolumn{2}{|c|}{$\begin{array}{c}\text { Ovulation within } 6 \text { months after } \\
\text { LOD }\end{array}$} & \multicolumn{2}{|c|}{$\begin{array}{c}\text { Pregnancy within } 6 \text { months after } \\
\text { LOD }\end{array}$} \\
\hline & $\begin{array}{c}\text { OR } \\
(95 \% \mathrm{CI})\end{array}$ & $\mathbf{P}$ & $\begin{array}{c}\text { OR } \\
(95 \% \mathrm{CI})\end{array}$ & $\mathbf{P}$ \\
\hline Age & $0.97(0.8$ to 1.2$)$ & 0.811 & $0.91(0.74$ to 1.1$)$ & 0.317 \\
\hline Weight & $0.92(0.8$ to 1.03$)$ & 0.140 & $0.94(0.86$ to 1.03$)$ & 0.197 \\
\hline BMI & $0.78(0.4$ to 1.4$)$ & 0.387 & $0.78(0.49$ to 1.23$)$ & 0.289 \\
\hline Initial AMH & $0.17(0.03$ to 0.96$)$ & 0.045 & $0.54(0.33$ to 0.89$)$ & 0.016 \\
\hline Initial AFC & $0.26(0.07$ to 0.89$)$ & 0.032 & $0.62(0.39$ to 0.98$)$ & 0.040 \\
\hline Initial VI & $0.001(0.00$ to 2.56$)$ & 0.086 & $0.46(0.2$ to 1.06$)$ & 0.068 \\
\hline Initial FI & $0.10(0.008$ to 1.46$)$ & 0.084 & $0.79(0.6$ to 1.03$)$ & 0.078 \\
\hline Initial VFI & $0.001(0.00$ to 0.74$)$ & 0.043 & $0.09(0.008$ to 0.99$)$ & 0.049 \\
\hline Post-LOD AMH & $0.28(0.09$ to 0.86$)$ & 0.027 & $0.44(0.21$ to 0.89$)$ & 0.023 \\
\hline Post-LOD AFC & $0.39(0.17$ to 0.92$)$ & 0.032 & $0.60(0.39$ to 0.92$)$ & 0.019 \\
\hline Post-LOD VI & $0.01(0.00$ to 0.65$)$ & 0.030 & $0.1(0.02$ to 0.65$)$ & 0.016 \\
\hline Post-LOD FI & $0.32(0.12$ to 0.86$)$ & 0.024 & $0.5(0.29$ to 0.87$)$ & 0.013 \\
\hline Post-LOD VFI & $0.006(0.00$ to 0.74$)$ & 0.038 & $0.09(0.01$ to 0.62$)$ & 0.014 \\
\hline
\end{tabular}

OR $(95 \% \mathrm{CI})$ odds ratio and its $95 \%$ confidence interval

Analysis using binary logistic regression analysis

\section{$\underline{\text { Discussion }}$}

Polycystic ovarian disease (PCOD) (22) is considered one of the most common endocrine problems among women. PCOD has a diverse range of causes that are not entirely understood (23). PCOD was diagnosed when 2 of the next 3 parameters were present: chronic anovulation, clinical or laboratory hyper-androgenism and clearly defined polycystic ovaries on ultrasound. The criteria are more flexible and permit the diagnosis in patients who had previously excluded by the $1990 \mathrm{NIH}$ criteria, such as anovulatory normo-androgenic or ovulatory hyper androgenic females with polycystic ovaries on ultrasound scan (4). Trans-vaginal ultrasound has become the preferred diagnostic technique for the identification of polycystic ovarian disease. 12 follicles or more measuring $2-9 \mathrm{~mm}$ in diameter, or increased ovarian volume $(10 \mathrm{~cm} 3)$ should be present on scanning to diagnose polycystic ovarian disease(2). 3D ultrasound has the power to improve the specificity and sensitivity of ultrasound in the diagnosis of PCOD (24). Laparoscopic drilling and $\mathrm{CC}$ have been established as the treatment of choice in CC-resistance (25).

The study objective was to determine the effect of endoscopic ovarian drilling (LOD) on Anti Mullerian hormone plasma level, stromal ovarian blood flow changes, by using 3D power Doppler and antral follicle count in females with Poly-Cystic Ovarian disease (PCOD) as primary outcomes and ovulation and pregnancy occurrence within 6 months after drilling with ovulation induction using clomiphene citrate of a daily dose of $150 \mathrm{mg}$ from the 3rd to 7th day as secondary outcomes, and whether this can explain the mode of action of drilling.

The study results were compared to previous studies that were held before to measure the results of endoscopic ovarian drilling in PCOD patients not responding to clomiphene citrate mainly with previous studies $(15,20$, 26 , and 27). 
This study did not show statistically significant difference between the 2 groups as regards general demographic data including the age, no. of previous miscarriage, weight and BMI. It was in agreement with those of $(15,20,26$, and 27).

The study conducted that the median parity was obviously significantly higher in females of group II (control group) which was in agreement with the studies of $(15,28)$.

In the current research, the mean initial AMH and the median initial AFC were higher among cases than control group. The mean initial AMH was $7.19 \pm 2.45$ for study group, and $2.23 \pm 0.69$ for group control and the median initial AFC was 29 for group I and 12 for group II when $\mathrm{P}$ value was $<0.001$.

This was in agreement with the study of (15) concerning the initial serum $\mathrm{AMH}$ which was $7.4 \pm 4.6$ for cases group pre LOD and $1.9 \pm 0.3$ for control group and for the initial AFC which was $29 \pm 2.4$ for cases group pre LOD and $13 \pm 1.9$ for control group. It also was in agreement with the studies of $(20,27)$.

In the current study, the mean ovarian FI, VFI and VI were higher between women of study when compared to control group. This was in agreement with the studies of $(4,15$, 27, and 29).

This study showed significant reduction in AMH serum level after LOD between women of cases group which became $3.84 \pm 1.51$ $\mathrm{ng} / \mathrm{ml}$ with [MPD $3.34 \mathrm{ng} / \mathrm{ml}, 95 \%$ CI (2.8 to 3.9), $\mathrm{p}<0.001]$.

This was in agreement with the study of (15) which was $4.2 \pm 2.5 \mathrm{ng} / \mathrm{ml}$ and also it was in agreement with the study of $(20,27)$.

This study showed significant reduction in AFC after LOD among women of cases group which became 14 with [MPD 14.9, $95 \%$ CI (13.9 to 15.8$), \mathrm{p}<0.001]$.

This was in agreement with the study of (15) which was $15 \pm 2.2$. And also it was in agreement with the studies of $(20,27)$.
In this study, there were significant reductions in FI, VI and VFI after than before LOD in study group. This was in agreement with the study of $(15,20$, and 27). But this was in disagreement with that of (26) who revealed a significant increase in ovarian FI, VI, and VFI after LOD in women with PCOD.

The cause that this study results were different from the previously mentioned study may be due to the technique of how endoscopic ovarian drilling was performed (number, depth of punctures, type of electrocautary needle, time of application of needle to the ovary and the power of electrocautary.

In this study, bilateral LOD was done by using monopolar electrocautary needle which was applied perpendicular to the ovary aided by a short duration of cutting current $40 \mathrm{~W}$ for 4-6 seconds in 4 puncture. In a study done by (26) bilateral LOD was done by using monopolar electrocautary needle which was applied perpendicular to the ovarian surface aided by a short duration of cutting current $30 \mathrm{~W}$ for 2-4 seconds in 4 puncture.

Another issue that may explain why our study results (regarding ovarian indices) were different from previous studies is the timing of performing the $3 \mathrm{D}$ power Doppler.

In the current study, the 3D power Doppler indices (FI, VI and VFI) were measured in 2 nd or the 3rd day of the menstruation before and after drilling.

In the study of Aliaa (26) the indices of 3D power Doppler (FI, VI and VFI) were measured before or after drilling in the day 11 or 12 of the cycle.

The controversy between our and Aliaa (26) results may be explained by different sample size which was smaller our study. The increasing number of included females provide better representation of the general populations.

In our study, of the included 25 women of group I, $20(80 \%)$ had ovulation, and 13 
(52\%) got pregnant within 6 months after drilling and by clomiphene citrate.

This was in agreement with (15) which had $73.9 \%$ ovulation rate and $26.1 \%$ spontaneous pregnancy rate.

\section{Conclusion}

This study showed that LOD had a significant decreasing effect on $\mathrm{AMH}$ serum level, AFC, and Ovarian Doppler indices of FI, VI and VFI in PCOD patients not responding to clomiphene citrate. It also showed that initial AMH, initial AFC, initial VFI, post-LOD AMH, post-LOD AFC, post-LOD VI, post-LOD FI and post-LOD VFI were significant indicators of successful ovulation and successful pregnancy within 6 months after drilling.

\section{$\underline{\text { References }}$}

1. Hart R, Hickey M, Franks S (2004): Definitions, prevalence and symptoms of polycystic ovaries and polycystic ovary syndrome. Best Pract Res Clin Obstet Gynecol 2004;18(5):671-83.

2. Balen AH, Laven JS, Tan SL, Dewailly D (2003): Ultrasound assessment of the polycystic ovary: international consensus definitions.Hum Reprod Update 2003 ;9:505-14.

3. Rotterdam ESHRE/ASRM-Sponsored PCOS Consensus Workshop Group (2004) Revised 2003 consensus on diagnostic criteria and long-term healthrisks related to polycystic ovary syndrome (PCOS). Hum Reprod; 19(1):41-7.

4. El Behery MM, Diab AE, Mowafy $H$, Ebrahiem MA, Shehata AE (2011): Effect of laparoscopic ovarian drilling on vascular endothelial growth factor and ovarian stromal blood flow using 3-dimensional power Doppler.Intern J Gynecol Obstet 2011;112:11921.

5. Pan HA, Wu MH, Cheng YC, Li CH, Chang FM (2002): Quantification of Doppler signal in polycystic ovary syndrome using three-di- mensional power Doppler ultrasonography: a possible new marker for diagnosis. Hum Reprod $2002 ; 17(1): 201-6$.

6. Ng EH, Chan CC, Yeung WS, Ho PC (2005): Comparison of ovarian stromal blood flow between fertile women with normal ovaries and infertile women with polycystic ovary syndrome. Hum Reprod 2005;20(7):1881-6.

7. Ronnie T, Yodfat S, Ron S, Hershkovitz R (2010): Characterization of pelvic organs by Doppler sonography waveform shape. Ultrasound Med Biol 2010;36(5):705-11.

8. La Marca A, Broekmans FJ, Volpe A, Fauser BC, Macklon NS (2009): ESHRE special interest group for reproductive endocrinology-AMH round table. Anti- Mullerian hormone $(\mathrm{AMH})$ : what do we still need to know? Hum Reprod 2009;24:2264-75.

9. Durlinger AL, Gruijters MJ, Kramer P, Karels B, Kumar TR, Matzuk MM (2001): Anti-Mullerian hormone attenuates the effects of FSH on follicle development in the mouse ovary. Endocrinology 2001;142:4891-9.

10. Pigny P, Merlen E, Robert Y, Cortet-Rudelli C, Decanter C, Jonard S (2003): Elevated serum level of anti-Mullerian hormone in patients with polycystic ovary syndrome: relationship to the ovarian follicle excess and to the follicular arrest. J Clin Endocrinol Metab 2003;88:5957-6.

11. Das M, Gillott DJ, Saridogan E, Djahanbakhch O (2008): Anti-Mullerian hormone is increased in follicular fluid from unstimulated ovaries in women with polycystic ovary syndrome. Hum Reprod 2008;23:2122-6.

12. Laven JE, Mulders AM, Visser J, Themmen AP, de Jong FH, Fauser BM (2004): Anti-Mullerian hormone serum concentrations in normo ovulatory and anovulatory women of reproductive age. J Clin Endocrinol Metab 2004;89:318-23.

13. Eldar-Geva T, Margalioth EJ, Gai M, Ben-Chetrit A, Algur N, Zylber-Haran E (2005): Serum anti-Mullerian hormone levels during controlled ovarian hyperstimulation in women in polycystic ovaries with and without hyperandrogenism. Hum Reprod 2005;20:1814-9. 
14. Abd El Aal DE, Mohamed SA, Amine AF, Meki AR (2005): Vascular endothelial growth factor and insulin-like growth factor-1 in polycystic ovary syndrome and their relation to ovarian blood flow. Eur J Obstet Gynecol Reprod Biol 2005;118:219-24.

15. El Mashad Ashraf I (2011): Impact of laparoscopic ovarian drilling on anti-Mullerian hormone levels and ovarian stromal blood flow using three-dimensional power Doppler in women with anovulatory polycystic ovary syndrome. Fertil Steril 2011;95:2342-6.

16. Amer S, Li TC, Ledger WL (2004): Ovulation induction using laparoscopic ovarian drilling in women with polycystic ovarian syndrome: predictors of success. Hum Reprod 2004;19:1719-24.

17. El-Halawaty S, Rizk A, Kamal M, Aboulhassan M, Al-Sawah H, Noah O (2007): Clinical significance of serum concentration of anti-Mullerian hormone in obese women with polycystic ovary syndrome.Reprod Biomed Online 2007;15:495-9.

18. Kwee J, Schats R, McDonnell J, Themmen A, de Jong F, Lambalk C (2008): Evaluation of anti-Mullerian hormone as a test for the prediction of ovarian reserve. Fertil Steril 2008;90:737-43.

19. Nardo LG, Gelbaya TA, Wilkinson H, Roberts SA, Yates A, Pemberton P (2009): Circulating basal anti- Mullerian hormone levels as predictor of ovarian response in women undergoing ovarian stimulation for in vitro fertilization. Fertil Steril 2009;92:1586-93.

20. Amer S, Li TC, Ledger WL (2009): The value of measuring anti-Mullerian hormone in women with anovulatory polycystic ovary syndrome undergoing laparoscopic ovarian diathermy. Hum Reprod 2009;24:2760-6.

21. Dewailly D, Catteau-Jonard S, Reyss AC, Maunoury-Lefebvre C, Poncelet E, Pigny $P$ (2007): The excess in $2-5 \mathrm{~mm}$ follicles seen at ovarian ultra sonography is tightly associated to the follicular arrest of the polycystic ovary syndrome. Hum Reprod 2007;22(6):1562-6.
22. Kollmann M, Martins WP, Raine-Fenning N (2014): "Terms and thresholds for the ultrasound evaluation of the ovaries in women with hyperandrogenic anovulation". Hum. Reprod. Update 20 (3): 463-4.

23. USMLE-Rx, MedIQ Learning, LLC. (2014): Stein-Leventhal syndrome, also known as polycystic overy syndrome (PCOS), is a disorder characterized by hirsutism, obesity, and amenorrhea because of luteinizing hormone-resistant cystic ovaries.

24. Raine-Fenning NJ, Campbell BK, Clewes JS, Kendall NR, Johnson IR.(2003):The reliability of virtual organ computer-aided analysis (VOCAL) for the semiquantification of ovarian, endometrial and subendometrial perfusion. Ultrasound Obstet Gynecol 22: 633-639.

25. National Institute for Clinical Excellence(2004): Fertility assessment for people with fertility problems. A clinical guideline. London: RCOG press.

26. Aliaa M (2014): Impact of laparoscopic ovarian drilling on E2/FSH Ratio and ovarian stromal blood flow in women with polycystic ovary syndrome. Hum Reprod. 2014; 13:651-5.

27. El Sayed SA (2015): Impact of Laparoscopic Ovarian Drilling on Ovarian Reserve and Ovarian Stromal Blood Flow Using three-Dimensional Power Doppler in Women with Anovulatory Polycystic Ovary Syndrome; ActaObstetGynecolScand 2015; 84(3):2605.

28. Api M, Gorgen H and Cetin A (2005): Laparoscopic ovarian drilling in polycystic ovary syndrome. Eur J ObstetGynecolReprodBioL; 119(1):76-81.

29. Amin AF, Abd el-Aal DE, Darwish AM, Meki AR (2003): Evaluation of the impact of laparoscopic ovarian drilling on Doppler indices of ovarian stromal blood flow, serum vascular endothelial growth factor, and insulin-like growth factor-1 in women with polycystic ovary syndrome. FertilSteril.; 79(4):938-41. (2017): 329-333 